\title{
Financial Soundness of Housing Finance Companies: Application of Altman Z- Score Model
}

\author{
B. Ramesh, P. Suvarchala Devi
}

\begin{abstract}
Housing financing industry is the essentially industry most of the housing financing companies contributing greatly to the development of our economy and have. Recently, some of the housing financing companies have started losing profits continuously and are on the verge of bankruptcy. The purpose of this paper is to study the financial position of housing companies by applying the famous Altman $Z$ score model to verify whether these companies really suffered financially during the period from 2015 to 2019,16 housing companies are considered for the analysis of the study. It was found that not all the housing finance companies were performing as expected.
\end{abstract}

Keywords: Altman z score, housing, finance, financial soundness

\section{INTRODUCTION}

$\mathrm{H}$ ousing finance is considered to be one of the basic human needs. The capital required to acquire or construct a house is large so that only a few individuals with high income can raise it from their own funds. "There is a great need and scope for the development of arrangements for supplying 1 (loans) finance for housing". [Bhole L.M. (1999), p. 253]. In simple terms, finance provided for acquiring a house is called "Housing Finance". In technical terms, housing finance means finance provided for building the house to individuals, corporate borrowers and builders. "It also includes developers loans provided to institutions for the construction of large residential projects. "Finance for housing is generally provided in the form of mortgage loan, i.e. it is provided against the security of immovable property of land and building. [Bhole L.M. (1999), p.253]. Thus we can say that housing finance is a specialised activity which is based on mortgage lending. To understand the housing finance first we need to understand what a mortgage loan is.

The Indian housing finance area has progressed significantly from its earlier phase of government control to an undeniably market oriented system times. establishment of institutions in Public and private sector such as the National Housing Bank, the Housing and Urban Development Corporation Limited and the Housing Development Finance Corporation Limited in the 1970s and 1980s carried the genuinely necessary concentration to the housing finance division and moved the framework into a higher development direction. decrease in its market share in the housing finance organizations. 1991 Economic Policies creates a path for progression of housing finance and fast development sector. Throughout years, the direction market orientation of housing finance system an empowering regulatory structure has lent the much desired liveliness to the housing finance sector. The dynamic quality is showed in the extreme rivalry among banks and the wide decisions accessible to borrowers. Lower interest rates, stable property costs, rising individual incomes and tax deductions for proprietor occupied homes have contributed to the expansion in the interest for has expanded under refinance the NHB, priority sector lending, increased budgetary allocations to the housing finance and expanded interest of private division lending organizations. Securitization of housing advances, despite the fact that at an underlying stage, has given an extra wellspring of reserves. Simultaneously, quick pace of urbanization and rising housing ambitions are resulting into an extending gap between the supply and demand of housing finance.

Since 96 percent of the urban housing deficiency is in the classifications of EWS and LIG, which signifies 38 million as on 2018, there is an expanded pushed on "Affordable Housing" in the present. Policy makers and Housing Industry are oriented towards reasonable housing to develop a comprehensive housing Finance sector. The builders and lending financial institutions have stirred to the colossal market potential for reasonable housing for lower income family units.

\section{REVIEW OF LITERATURE}

Collins (1980) evaluate the difference between different models to measure the bankruptcy, the research discovers though various models deliver good results still Z-score proves to be better one. Grice and Ingram (2001) give an reason for the genaralibility of software of Z-rating. The study discoveries adverse results in software of Z-score in recent intervals and to manufacturing companies, however effective outcomes for forecasting distress aside from monetary wreck because it modified into first of all developed for financial ruin. Bal and Raja (2013) have strive the earnings manage and strategies to assume creditworthiness scenario. This take a look at practices Z-rating to forecast economic distress of IOC. 
Altman (1968), has evolved the idea of $\mathrm{Z}$ rating. In his paintings he tested the economic position with the help of ratio evaluation, which changed into similarly analysed with the help of a couple of discriminate analyses, through which a discriminate coefficient turn out to be decided. This version become articulated to determine the economic wreck of any company. Johan (2006) follow the $\mathrm{Z}$ rating to measure the economic average performance of small agency companies in Kenya, and to determine the distress stage via cyclical idea. Anjum (2012) take a look at the organisation failure, ordinary variations that were undertaken within the Altman $\mathrm{Z}$ rating model over the length from 1968 to 1993 and the assessment amongst various models superior in respect of economic disaster.

Manoj Kumar and MadhuAnand, (2013) evaluated the Kingfisher airlines constrained (KAL), they decided that the overall performance of reading financial health (and distress) of KAL the use of Altman "es Z rating is nice. Their take a look at experiential that the organization ${ }^{\text {ee }} \mathrm{s}$ monetary fitness changed into little by little terrible at some point of the period of have a look at i.e from 2005 to 2012. McCarthy, (2017) the principle look at of this studies became to find out whether the two forensic accounting tools that is the Altman $\mathrm{Z}$ rating version and the Beneish $\mathrm{M}$ score version might predict the organization failure and monetary manipulation of Enron organization.the researcher additionally said that every Altman $\mathrm{Z}$ rating version and Beneish $\mathrm{M}$ rating model need for use at the equal time for the cause of audit Apoorva\&Sneha Prasad, (2019): in accordance their look at, with the useful resource of making use of Altman $\mathrm{Z}$ rating on 7 agencies indexed on the BSE, they decided that the model is $85 \%$ correct and effective for three years preceding to the existence of the occasion of monetary disaster. in addition they counseled that the Altman $\mathrm{Z}$ rating model can be widely used by the stakeholders of the company so that their economic interest stays covered.

\section{GOALS OF THE OBSERVE}

To have a look at the economic fitness of housing finance agencies presenting finance in India.

\section{METHODOLOGY}

The person of the observe is in quantitative. The observe used secondary information. The facts used for the study is from 2015 to 2019.It tries to examine the economic fitness of housing finance businesses indexed in stock marketplace in india.it covers a sample of sixteen housing finance groups in India. The list of businesses used for the look at is in underneath table. The information is taken from cash manipulate. Altman ' $Z$ ' rating is used to examine the economic statements of the organizations. For the analysis of information excel 2010 has been used.
Table 1:List of housing financing companies in India.

\begin{tabular}{|l|l|}
\hline S.NO. & Name of the company \\
\hline 1 & HDFC \\
\hline 2 & LIC \\
\hline 3 & PNB \\
\hline 4 & REPCOHOME \\
\hline 5 & GIC \\
\hline 6 & SRG \\
\hline 7 & INDIA HOME LOAN \\
\hline 8 & INDBANK HOUSING \\
\hline 9 & INDIABULLS \\
\hline 10 & HUDCO \\
\hline 11 & CAN FINANCE \\
\hline 12 & AAVAS FINANCER \\
\hline 13 & RELIANCE HOUSING FINANCE \\
\hline 14 & AKMESTAR \\
\hline 15 & SAHARA \\
\hline 16 & DEWAN \\
\hline
\end{tabular}

\section{Source: money control 2019}

\section{Altman's Z score}

The most popular model, Dr,Edward I, Alman's Multiple Discriminate Analysis has been used as tool to analyse the collected data. The formula used to evaluate the " $Z$ " score analysis for Non-Manufacturing firms:

\section{Z-Score estimated for non-manufacturers: \\ $X_{1}=$ (current assets - current liabilities) / total assets \\ $X_{2}=$ retained eamings / total assets \\ $X_{3}=$ eamings before interest and taxes / total assets \\ $X_{4}=$ book value of equity / total liabilities}

\section{Z-Score bankruptcy model:}

$$
Z=6.56 X_{1}+3.26 X_{2}+6.72 X_{3}+1.05 X_{4}
$$

\section{Zones of discriminations:}

\section{$Z>2.6$ - "Safe" Zone}

$1.1<Z<2.6-$ "Grey" Zone

$Z<1.1$ - "Distress" Zone

\section{DATA ANALYSIS AND INTERPRETATION}

A.Working Capital to Total Assets: This extent is an extent of affiliation's liquidity to meet cash related responsibilities and further exhibit shows task of association assets into liquid and non-liquid assets. A higher extent shows more grounded budgetary position. The Table 2 shows the association of stirring cash to indicate assets in test associations. The mean advantage of working capital/Total assets is 0.93 . Among the model associations, all of the associations are having positive. It shows that these associations are in an average circumstance to keep up appropriate stirring capital as for mean assets.

B. Retained Earnings to Total Assets: Retained Earnings to Total Assets is a measure how much an association relies upon commitment, or impact. It is an extent of total profit after some time as a degree of full scale assets. The Table 2 shows that the mean held pay on outright assets is - 0.05.all the associations ought to grow the advantages for getting held benefit.

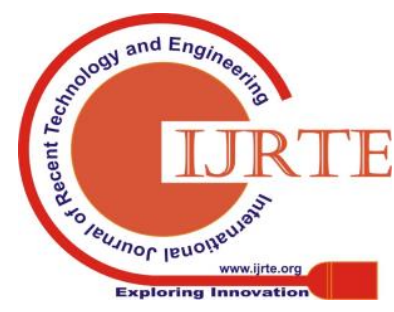


C.EarningsbeforeInterest \& Tax to Total Assets: It is an extent of the gainfulness of the organization's advantages, self-governing of any cost or impact factors. It suggests the present productivity in degree of the supreme assets. The Table 2 shows that the mean benefit before interest and appraisal to signify assets is 0.12 , exhibiting that the extent is irrelevant. In this manner it will in general be concluded that the present advantage in connection to signify assets is low and irrelevant.

D.Book Value of Equity to Total Liabilities book estimation of significant worth to mean liabilities insinuates association among esteem and full scale liabilities. It shows that how far the benefits of the association rot before the business gets cleared out. The Table 2 shows that the market estimation of significant worth to mean liabilities was - 1.08.all the associations ought to grow the book estimation of significant worth.

\section{Z SCORE ANALYSIS}

\section{Table 2: Descriptive analysis}

The Table 2 shows the values of $\mathrm{Z}$ score to interpret the health of different sample companies. In case the $\mathrm{z}$ score is greater than 2.6, then the companies are labeled in safe zone, whereas the companies whose $\mathrm{z}$ score lies between 1.1 and 2.6 are labeled as gray zone. The companies whose $\mathrm{z}$ score is below 1.1 are termed as distressed companies. Therefore these companies should improve their financial health to avoid bankruptcy. The main idea of the study is to find the companies which lie in "distress zone" and identify the reasons for distress.

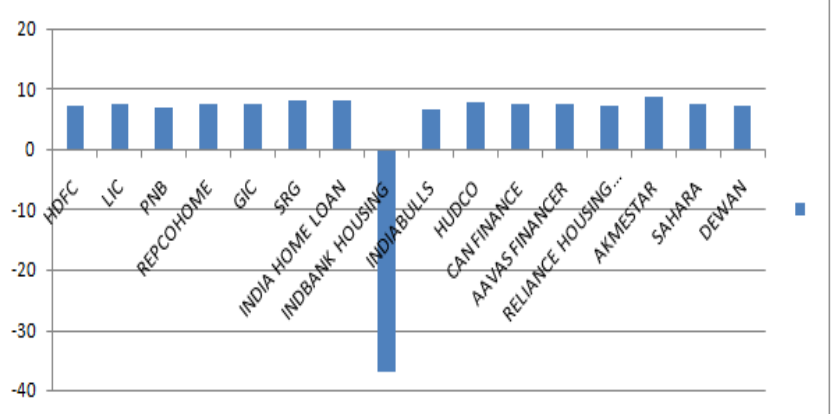

Figure 1: Z-Score Analysis Diagram

The figure 1 shows the " $Z$ score values" of sample of 16 Housing Finance Companies in

\begin{tabular}{|c|c|c|c|c|}
\hline & $\mathrm{WC} / \mathrm{TA}$ & $\mathrm{RE} / \mathrm{TA}$ & EBIT/TA & BVA/TL \\
\hline HDFC & 0.91 & 0.03 & 0.13 & 0.18 \\
\hline LIC & 0.99 & 0.01 & 0.10 & 0.09 \\
\hline PNB & 0.93 & 0.01 & 0.09 & 0.11 \\
\hline REPCOHOME & 0.92 & 0.02 & 0.09 & 0.15 \\
\hline GIC & 0.93 & 0.02 & 0.10 & 0.10 \\
\hline SRG & 0.98 & 0.04 & 0.12 & 0.29 \\
\hline INDIA HOME LOAN & 0.94 & 0.02 & 0.08 & 0.52 \\
\hline INDBANK HOUSING & 0.99 & -1.15 & 0.49 & -20.46 \\
\hline INDIABULLS & 0.82 & 0.04 & 0.13 & 0.15 \\
\hline HUDCO & 0.98 & 0.02 & 0.09 & 0.24 \\
\hline CAN FINANCE & 0.91 & 0.00 & 0.10 & 0.09 \\
\hline AAVAS FINANCER & 0.89 & 0.03 & 0.07 & 0.10 \\
\hline RELIANCE HOUSING FINANCE & 0.97 & 0.01 & 0.10 & 0.12 \\
\hline AKMESTAR & 0.95 & 0.05 & 0.11 & 0.69 \\
\hline SAHARA & 0.99 & 0.01 & 0.06 & 0.26 \\
\hline DEWAN & 0.93 & 0.01 & 0.11 & 0.09 \\
\hline Mean & 0.93 & -0.05 & 0.12 & -1.08 \\
\hline
\end{tabular}

India Excluding one company namely Indbank Housing, all other sample companies are in sae zone. In case the sample company is having $\mathrm{Z}$ score less than 1.1, then there failure is certain and probably turn into bankruptcy within next a years. The study found that most of the sample companies are falling in the safe zone $\mathrm{z}$ score value is more than 2.6. Hence there is an urgent need for the management of the company to examine and reduce the financial distress of the company.

\section{CONCLUSION:}

In this competitive world survival of housing finance companies are very difficult. they need to apply moderate regulatory rules and regulations, they should also concentrate on NPA then they can generate revenue. Almost all the companies retained earnins, profits and book value of the assets very low, so it should improve.

\section{REFERENCES:}

1. Collins, R. A., An Empirical Comparison of Bankruptcy Prediction Models, Financial Management, summer 1980, v9 (2), 52-57.

2. Grice, J.S. and Ingram, R.W. (2001) Tests of the Generalizability of Altman's Bankruptcy Prediction Model. Journal of Business Research, 54, 53-61.

3. Edward I. Altman (1968)Financial Ratios, Discriminant Analysis and the Prediction of Corporate Bankruptcy.

4. SanobarAnjum(2012) Business Bankruptcy Prediction Models: A Significant Study of the Altman's Z-Score Model.

5. Manoj Kumar \& Madhu Anand, (2013). "Assessing Financial Health of a Firm Using Altman's Original and Revised Z-Score Models: A Case of Kingfisher Airlines.

6. Apoorva D.V"(2019) “Application of Altman Z Score Model on Selected Indian Companies to Predict Bankruptcy" International Journal of Business and Management Invention (IJBMI), vol. 08, no.01, 2019, pp 77-82.

7. Bal, R. G. (2015). Prediction of financial distress using Altman Z-score: a study of select FMCG Companies. Indian Journal of Applied Research.

8. McCarthy, J. (2017). Using Altman Z-score and Beneish M-score Models to Detect Financial Fraud and Corporate Failure: A Case Study of Enron Corporation. International Journal of Finance and Accounting.

9. L M Bhole(1999),Financial Institutions and Markets.

10. www.moneycontrol.com

11. Www.bseindia.com

12. www.nseindia.com

13. http://en.wikipedia.org 